This final great undertaking, like the many which had gone before, was a tribute to Lensen's long and consistent devotion to learning in the fundamental and profound sense. It reflected his indomitable spirit, restless curiosity, intellectual acumen, and his driving desire to understand the world around him and to communicate his findings and interpretations to students and readers. His memory as a warm, friendly, and generous person will be perpetuated and recalled by those students, colleagues, and friends who knew him best.

John A. White

University of Hawaii

\title{
WITOLD S. SWORAKOWSKI, 1903-1979
}

Born on January 16, 1903, to Polish parents in Suceava, Rumania, Witold S. Sworakowski completed his elementary education and part of his secondary education in that country. After graduation from a gymnasium in Vienna, he studied engineering in Lwów and subsequently jurisprudence in Cernauți. He received his advanced degree in diplomatic history and international law from the Academy of Political Science in Warsaw in 1933. A promising career in Poland's foreign service ended after World War II, when he resigned in protest against the Soviet-directed communization of his country.

Mr. Sworakowski came to the Hoover Institution in 1947 as a Slavic research fellow under a Rockefeller Foundation grant. Five years later, he was appointed an assistant professor and subsequently advanced to a full professorship at Stanford University. His positions in the Hoover Institution included posts as curator for the Polish, West European, and East European collections, assistant director, and finally associate director in charge of library operations. During this last assignment, he doubled the number of bound volumes, which currently have passed the one and a half million mark, and brought in literally hundreds of archival units to augment the collections of primary source materials, which now number more than four thousand.

Apart from his administrative work at the Hoover Institution, Professor Sworakowski taught at Stanford University and also spent a considerable amount of time on research. Author and editor of five books and more than twenty-five scholarly articles, he continued writing until shortly before his death on January 15, 1979.

Witold Sworakowski was a unique individual whose enthusiasm for work affected everyone around him. An intellectual in the European sense of the word, Professor Sworakowski was a man of high principle and great moral courage. Loyalty and devotion to his adopted country, of which he became a citizen in 1953, as well as to the Hoover Institution were absolutes. A skilled diplomat, he knew how to bring divergent views together and how to reconcile opposites. It was a joy to work with this man, whose feeling for history inspired colleagues and students alike. He had an uncanny talent for "outguessing the future," for uncovering primary source materials which he then managed to acquire with tact and dispatch. In these efforts he ranks with such illustrious predecessors as Professors E. D. Adams, Frank Golder, and Ralph H. Lutz, who also served both the Hoover Institution and Stanford University. Ten years ago, the Hoover Institution established the Witold Sworakowski Collection on Poland to honor him and to perpetuate his name.

Aside from teaching, administrative work, collecting books and archives, research, and scholarly writing, Professor Sworakowski also helped numerous refugees from Eastern Europe and the Soviet Union to settle in the United States. A member of the Polish Institute of Arts and Sciences in America, he served as president of the Captive Nations Committee for Northern California and, only a few days before his death, received honorary membership in the Polish-American National Congress. 
A scholar who spoke six languages fluently and could read five additional ones, a wonderful teacher whom his graduate students will never forget, a fighter for human rights long before this became fashionable, a collector of historical documentation which will remain a monument to his efforts on behalf of thousands of visiting researchers, a unique repository of talents, Witold Sworakowski will be missed by friends all over the world.

RICHARD F. StaAR

Hoover Institution 